\title{
Social entrepreneurship: A solution for transforming the disadvantaged community of Nellmapius
}

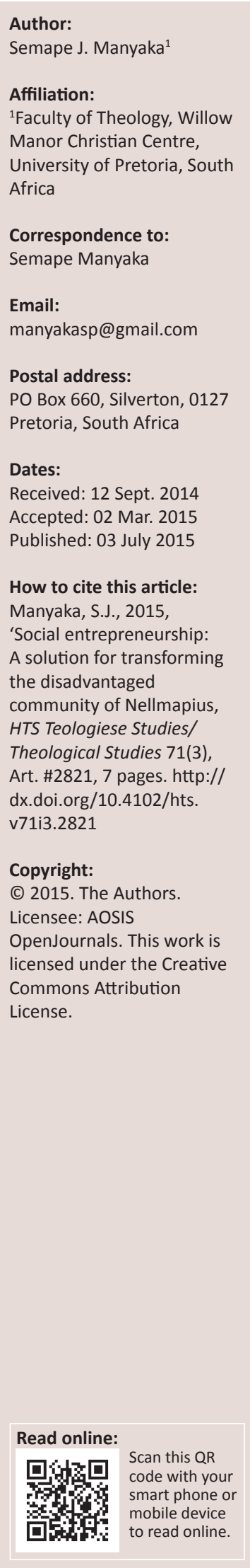

In this article, I investigate the concept, social entrepreneurship, as a potential lever in economic and social transformation of the poorest-of-the-poor community of Nellmapius township, east of Pretoria, South Africa. I identify definitions of 'entrepreneurship' and 'social entrepreneurship', and delve into the historical development of the concept 'entrepreneur'. South Africa is in an era where it needs more new venture creation. Hence, I have studied new venture formation, especially from the perspective of Schumpeter's theory of ways of forming a new firm. South Africa lags behind in new venture development compared to other developing countries; I investigated the causes behind this and suggest remedies to address this. Postfoundationalist practical theology is seen as a way of doing theology in the midst of those who suffer poverty and lack. The methods of this approach are dealt with in this article, which also asks what theology can bring to the table of interdisciplinary engagement?

\section{Introduction}

South Africa is characterised by poverty and high unemployment rates, and as a result, needs more social entrepreneurs who will develop models and systems to transform communities. In this article, I look into the transformation of the disadvantaged community, Nellmapius township, east of Pretoria; in particular, I want to focus on social entrepreneurship as a method to eradicate poverty. Bearing in mind the high unemployment statistics in the country, I will investigate the concept of social entrepreneurship as a possible career path. The mission of the social entrepreneur is not profit maximisation, but to create social value that will promote social transformation (Peredo \& McLean 2005:12).

Mair and Marti (2006:38) defined social entrepreneurship as 'typically referring to a process or behaviour; social entrepreneurs focus ... on the founder of the initiative; social enterprises refer to the tangible outcome of social entrepreneurship'.

A positive aspect of the social entrepreneurship model is that these entrepreneurs can generate income to sustain the project whilst simultaneously making an impact on some of the social problems at hand. Social entrepreneurs enjoy a degree of freedom in terms of donors who are sometimes unsympathetic to local ways of doing things and prefer to impose their own systems, which are not necessarily helpful at grass roots level.

\section{The community of Nellmapius}

Nellmapius is a township situated east of Pretoria and south of Mamelodi in South Africa. According to the most recent census of 2011, the Nellmapius population consists of about 56108 individuals, of whom the vast majority are black, and about 1019 are coloured people (Statistics South Africa 2011). More than half of the population is unemployed; others work in temporary and low-paid jobs.

A small proportion of the inhabitants of Nellmapius live in bond houses, whilst the majority live in one-roomed, so-called Reconstruction and Development Programme (RDP) houses which were received from the Government. During the course of 2014, shacks were built along railway lines close to Mamelodi.

Nellmapius has only one clinic that services the whole area. There are four primary schools and one high school. There are many unregistered early childhood development (ECD) centres scattered across the Nellmapius area. However, Nellmapius boasts having many churches: at first glance, it appears that there are two churches on every street. This indicated that the people of Nellmapius are believers. 
From my personal observation, it appears that almost all spaza shops in Nellmapius are owned by foreign nationals, who are also visible as street vendors and car mechanics. From the perspective of this article, this is a concern: where are the South African entrepreneurs? What factors inhibit South Africans from running businesses and engaging in entrepreneurship?

\section{Historical development of the concept of entrepreneur}

When writing about the entrepreneur it is important to understand what we mean by the word. It originated in French economics as early as 1700 (Herrington, Kew \& Kew 2009:11). It refers to someone who 'undertakes'; not an undertaker in the sense of a funeral director, but someone who undertakes a significant project or activity (Chell 2007:8; Herrington et al. 2009:11).

Scholars have been broadening the definition since 1734, when Cantillon, as quoted in Hamilton and Harper (1994:3), said 'entrepreneurs are non-fixed income earners who pay known costs of production but earn uncertain incomes'. He went further, and described an entrepreneur as a specialist in taking risk.

Jean-Baptiste Say (1767-1832) stipulated that the entrepreneur represented the catalyst for the development of products a superior labour. He continued, 'an entrepreneur shifts economic resources out of an area of low productivity into an area of higher productivity and greater yield' (Herrington et al. 2009:11).

Schumpeter (1934:78) identified entrepreneurs as 'innovators who carry new combinations', thereby precipitating economic development. Almost thirty years later, McClelland (1961:237) argued that 'an entrepreneur is a person with high need for achievement $[N-A c h]$. He is energetic and a moderate risk taker'. Well-known author Peter Drucker (1964) proposed that an entrepreneur searches for change, responds to it, and exploits opportunities. Innovation is a specific tool of an entrepreneur; hence, an effective entrepreneur converts a source into a resource.

Bull and Willard (1993), commenting on existing literature at the time, noted the different routes scholarship had taken in grappling with the concept:

The first ... focus [is] on the definition of the word 'entrepreneur'. A second consider[s] the trait approach, i.e., the study of the psychological traits of people identified as entrepreneurs; another is the study of strategies of success, reasons offered to explain the success of new ventures. A fourth ... is the study of the formation of new ventures, and lastly [the] papers that study the effect of environmental factors on entrepreneurial actions. (p. 184)

Parker (2004) expanded on Schumpeter's concept of the entrepreneur as an innovator, as being responsible for 'the doing of the new thing, or the doing of things already done in a new way'. This could involve the following:

- the creation of a new product

- a new method of production
- the opening of the new market

- the capture of a new source of supply

- a new organisation of industry.

Casson (2010:7) referred to entrepreneurs as 'funny animals; they take a crucial decision to commit resources to the exploitation of new ideas'.

This short historical overview shows how difficult it is to reach one understanding of the concept of entrepreneur. In this article, I adopt an inclusive approach. First, it should be noted that both men and women are capable of being entrepreneurs, even though there are more male entrepreneurs. Herrington and Turton (2012:7) noted that in terms of demographics, South Africa's gender gap widened in early-stage activity, with a total early-stage entrepreneurial activity (TEA) showing 61\% male involvement versus 39\% female involvement.

\section{Starting a new venture}

Given my aim - looking into methods and perspectives that can assist transformation of the poor community of Nellmapius - I look first at how to start a sustainable venture. As there is so much unemployment in South Africa, this could be a possible career path for some. For this I found the Schumpeter (1934) theory to be the most appropriate, as it involves the creation of new products or new methods of production, the opening of new markets or capturing new sources of supply, or the new organisation of industry (Parker 2004:41).

The disadvantaged community of Nellmapius could start small businesses rather than wait for Government grants or expecting other people to employ them. For this to be possible, the following conditions must be met (Bull \& Willard 1993:183):

- task-related motivation

- expertise

- expectation of personal gain

- a supportive environment.

\section{Task-related motivation}

There is always the question of what makes a person an entrepreneur, or what motivates an entrepreneur to undertake the new venture? McClelland (quoted in Bull \& Willard 1993:188) identified three characteristics of entrepreneurs that he relates to their need for achievement:

- a desire to accept responsibility for solving problems, setting goals and reaching goals through their own efforts

- a willingness to accept moderate risks, not as a function of chance, but as a skill

- a desire to know the outcomes of their decisions.

These three characteristics also sum up the tasks of the entrepreneur.

He argued that, most frequently, what motivates entrepreneurs is not only the desire for monetary reward, but also 
a need for achievement; that at the end of a successful undertaking there will be a sense of satisfaction (McClelland 1961:233-237).

Amit, Glosten and Muller (1993), quoted in Parker (2004:76), identified four traits shared by most entrepreneurs:

- a need for achievement

- internal locus of control

- above-average risk taking propensity

- a tolerance of ambiguity.

\section{Expertise}

A new venture does not happen by chance; it needs skills. Cooper (1985) notes not only technical skills are needed, because technical expertise alone is not an assurance of success. Mentors who can support the entrepreneur are also needed. In the aforementioned section, I mentioned solving problems and setting goals: these are skills that any entrepreneur must learn. Casson (2010:8) observes judgment is the ability to come to a sound, defensible decision in the absence of complete information'. The entrepreneur must acquire the skill of judgement because without this, he or she cannot build a new venture.

Cooper (1985) used the term 'incubator organisation' to describe the entrepreneur's place of employment prior to the founding of the new venture. The Oxford Advanced Learner's Dictionary (Hornby 2004) defines 'incubator' as equipment in a hospital in which new babies are placed to help them survive if they are weak or born too early. Gissy (1984:20) argues that a new way of developing new businesses is an 'industrial incubator'. Incubators help the entrepreneur's new venture to overcome the liabilities of 'newness', particularly the lack of (Bull \& Willard 1993:189):

- role models

- standardised communication channels

- trust and credibility

- established clientele.

Indeed, skills play an important role in the life of the entrepreneur. For instance, the lack of managerial skills is also likely to hinder the entrepreneur from major success in his or her undertaking. He or she must have the capacity of creating the management systems that will enable and support the running of the business.

\section{Expectation of gain for self}

One of the motivations of an entrepreneur is self-gain. This could be in the form of money to afford to buy necessities or the things that one likes. More important than this, however, entrepreneurs need money to sustain the business or the new venture to achieve a 'satisfactory outcome' from the new venture. Others would gain independence, with the sense of being in power, and self-control (Bull \& Willard 1993:184).

\section{Supportive environment}

The environment has the potential to build or destroy the new venture. Thus, it is important to know what elements create a supportive environment. Most supportive environments are beyond entrepreneurs themselves, such as making the procedure of registering a new business easily and quickly (Musara \& Gwaindepi 2014:12). Encouragingly, in 2011 an amendment of the Companies Act of 2008 saw the removal of restrictive regulatory frameworks, less administration or red tape when registering a business, and reduced financial reporting requirements for small businesses (Musara \& Gwaindepi 2014:13).

Bull and Willard (1993) mentioned three forces that potentially stimulate the growth of a new firm in an industry, namely new technology, new markets and deregulation or shifts in Government regulation. The environment in which the entrepreneur operates should be as favourable as possible. Government policies and legislation must always support the establishment of the new venture or a firm.

Most entrepreneurial innovations are collective achievements of many people, in the public and private sectors, who develop an infrastructure that supports entrepreneurship (Van de Ven 1993). Our envisioned entrepreneurial activities cannot be successful unless others help create a supportive environment under which they would operate.

Herrington et al. (2009:14) remarked, 'institutional characteristics, culture, education, the regulatory environment, national demographics and the social culture of the nation all play a part in shaping the country's entrepreneurial landscape'.

\section{The concept of social entrepreneurship}

According to Martin and Osberg (2007:34), 'the social entrepreneur aims for value in the form of large-scale, transformational benefits that accrue either to a segment of society or to society at large'. Social entrepreneurship is about not only being paid for entrepreneurs' innovation, but about giving value to the under-served, neglected, and marginalised sections of our society. Martin and Osberg (2007:35) defined the process of becoming a social entrepreneur in three stages:

- identifying a stable but inherently unjust equilibrium that causes the exclusion, marginalisation, or suffering of a segment of humanity that lacks the financial means or political clout to achieve any transformative benefits on its own

- identifying an opportunity in this unjust equilibrium, developing a social value proposition, and bringing to bear inspiration, creativity, direct action, courage, and fortitude, thereby challenging the stable state's harmony

- forging a new, stable equilibrium that releases trapped potential or alleviates the suffering of the targeted group, and through imitation and the creation of a stable ecosystem around the new equilibrium, ensuring a better future for the targeted group or even society at large. 
According to this view, the social entrepreneur sees a problem in the community, he or she becomes alert to the opportunities that arise from the problem, and he or she devises a system for solving, or at least addressing, the problem.

Dees (1998:4) defines the entrepreneurial aspect of social entrepreneurship as including:

- the recognition and relentless pursuit of new opportunities to further the mission of creating social value

- continuous engagement in innovation and modification

- bold action undertaken without acceptance of existing resource limitation.

More recently, Austin, Stevenson and Wei-Skillern (2006:2) defined social entrepreneurship as 'innovative, social valuecreating activity that can occur within or across the nonprofit, business, or government sectors'. The mission of social entrepreneurship is bringing betterment to those who have been marginalised so that they can transform their conditions.

Chell (2007:13) noted that in the past social and community businesses tended to be grant-dependent, non-self-sustaining, and employed non-entrepreneurial staff. Even today, many non-profit organisations have no plans to make money to sustain their organisation. Personally, I have seen many non-profit organisations collapse because they could not obtain donor support. Chell (2007:13) asserts that 'social and community business should pursue their endeavours in a thoroughly entrepreneurial way'.

In the social arena, social entrepreneurs exhibit the risktolerance, innovation, and 'pro-activeness' displayed by commercial entrepreneurs in their setting (Peredo \& McLean 2005:10). Social entrepreneurship is a way of looking into social problems through innovative thinking. It seeks to identify problems and to be capable of seeing the opportunities embedded in the problems, and has the ability to design models to overcome problems.

This kind of innovative thinking is what is needed in South Africa. Innovative thinking is not waiting for Government to supply redress, but creating a model to address lacks and then offering Government and the private sector the opportunity to collaborate in solutions to the community problem. Social entrepreneurs are thus not only consumers, but also producers.

\section{Differences between entrepreneurship and social entrepreneurship}

Chell (2007) defines the difference between entrepreneurship and social entrepreneurship as follows:

Social entrepreneurship is focusing on the social mission, to bring a solution to the social problem facing a particular community; rather than focusing on profit making. Whatever has been made out of their entrepreneurship activity, will assist in sustaining the enterprise. (p. 9; [author's own emphasis])
To put it simply, social entrepreneurs do work for profit, just like entrepreneurs who work to produce a surplus, which translates into profit. However, social entrepreneurs make the profit not for personal gain, but to sustain their enterprise or business, and to continue helping the community, whereas entrepreneurs work for personal profit or wealth creation.

\section{Entrepreneurship in the South African context}

South Africa has been described as a country where poverty is very high and this is unacceptable (Statistics South Africa 2014); youth unemployment in particular is very high (Herrington et al. 2009:12). Entrepreneurship can help alleviate this situation. As early as 1995, Trevor Manuel, former minister of Trade and Industry, identified unemployment as one of the major problems facing the new regime. He addressed the role of entrepreneurship when he said 'small, medium and micro enterprise is an important vehicle to address the challenges of job creation, economic growth and equity in our country' (Herrington et al. 2009:12).

As we have seen, Schumpeter (1934) was the earliest economist to argue new firm creation could be the solution to growing the economy, eliminating unemployment and overcoming poverty, resulting in community transformation. Even non-profit organisations must learn to operate entrepreneurially. So, what is the level of entrepreneurial activity in South Africa?

Amra, Hlatshwayo and McMillan (2013:8) identified the South African informal sector as accounting for $28 \%$ of employment in the country. Overall, micro and small businesses accounted for $27 \%$ - 34\% of the country's total Gross Domestic Product in 2006 (South Africa, Department of Trade and Industry 2008:1).

Gree and Thurnik (2003) argued that the contribution of small and medium enterprises (SMEs) sector cannot be sustained without the creation of new SMEs. If the creation of new SMEs is not possible, South Africa risks economic stagnation (Herrington et al. 2009). Failing to develop adequate numbers in terms of new SMEs, unemployment and poverty rates will become more significant. Mass and Herrington (2006) observed that the creation of a new firm involves a twostaged process. The first phase is start-up, a three-month period during which individuals identify the products or services that the firm will trade in, access resources, and put in place the necessary infrastructure, such as staff. The next phase, a period stretching between 3 and 42 months, is when the business begins to trade and compete with other firms in the market place. In South Africa, most SMEs cannot go beyond the second phase into full sustainability; this means SMEs do not complete the developmental stages in new firm creation.

Over a number of years, studies by the Global Entrepreneurship Monitoring (GEM) group have shown conclusively that South Africa lags behind other developing countries in promoting early-stage entrepreneurial activity, 
and that the low level of early-stage entrepreneurial activity in South Africa is influenced by (Herrington et al. 2009:87):

- a low level of overall education, especially in mathematics and science

- social and entrepreneurial factors that do not encourage entrepreneurship as a career path of choice

- lack of access to finance, particularly in the microfinancing area

- a difficult regulation environment.

Olewale and Garwe (2010) differentiated between internal and external factors that contribute to South African SMEs achieving limited growth:

Internal factors:

- access to finance

- lack of managerial skills

- location and networking

- investment in information technology and cost of production.

External factors:

- economic variables and market stability and growth

- crime and corruption

- labour, infrastructure and regulation.

\section{The South African Government's role in entrepreneurship}

Since 1994, the democratically elected Government has promulgated many policies to promote entrepreneurial activities in South Africa. In March 1995, it released the White Paper on National Strategy for the Development of Small Business in South Africa (South Africa, Department of Trade and Industry 1995). It articulated the Government's rationale for small business promotion:

With millions of South Africans unemployed and underemployed, the Government has no option but to give its full attention to the fundamental task of job-creation, and to generating sustainable and equitable growth. Small, medium, and micro-enterprises (SMMEs) represent an important vehicle to address the challenges of job creation, economic growth and equity in our country. Throughout the world, one finds that SMMEs are playing a critical role in absorbing labour, penetrating new markets and generally expanding economies in creative and innovative ways. We are of the view that with appropriate enabling environment-SMMEs in this country can follow these examples and make an indelible mark on this economy. Stimulation of SSMEs must be seen as part of an integrated strategy to take this economy into a higher road - one in which our economy is diversified, productivity is enhanced, investment is stimulated and entrepreneurship flourishes. (p. 7)

Some of the initiatives meant to promote entrepreneurial activities in South Africa include the (Fury 2010):

- Small Business Development Agency (SEDA)

- Community Self-Employment Centres (COMSEC)

- National Youth Development Agency (NYDA)

- Industrial Development Corporation (IDC).
In its quarterly Labour Force Survey issued in July 2014, Statistics SA announced that 5.2 million people, or $25.5 \%$ of the population in South Africa, are unemployed (Statistics South Africa 2014). This is alarming and raises the question: just how effective are Government initiatives in fighting unemployment? As far as I am concerned, the South African Government has good intentions and policies to assist the entrepreneurs, but these have not been very effective. It appears the Government is struggling with the issue of implementation.

Total entrepreneurial activities are low and an upward trend has not been maintained. According to Herrington and Turton (2012):

The country's total entrepreneurial activities did increase in 2010 (from 5.9\% in 2009 to $8.9 \%$ in 2010) and then remained constant in 2011. In 2012, however, South Africa's TEA rate has dropped to $7.3 \%$. (p. 40$)$

The National Development Plan (South Africa, National Planning Commission 2011:91) identified three priorities:

- raising employment through faster economic growth

- improving the quality of education, skills development and innovation

- building the capacity of the state to play a developmental, transformative role.

In this article, I emphasise that entrepreneurial activity is the major route South Africa should be taking to alleviate poverty and unemployment. Entrepreneurship should be promoted as a career path, especially as unemployment is very high. With increased employment, including self-employment, poverty can be alleviated and, over time, eliminated. The marginalised and poorest-of-the-poor must be mobilised to realise that their future is in their hands. Ultimately, it is the purpose of Government to empower the poorest-of-thepoor communities, such as in Nellmapius. It is the role of all stakeholders (i.e. community leaders and professionals who live and work in Nellmapius) to inform the community about Government's plans and to work together to help the community to start small businesses. The next section focuses on the role of practical theologians and faith based organisations as stakeholders in poverty alleviation and social transformation in Nellmapius.

\section{Postfoundationalist practical theology}

I work within a practical theology framework, which clearly has a role in community empowerment. I start by asking the questions: what is practical theology? How can our practical theology help South Africans to develop entrepreneurial activities that can release the human potential in communities so that community members can take charge of the condition of their lives?

Browning (1996:8) says 'human nature is practical in thinking'. In doing practical theology, we move from practice to theory and back to practice in a process described 
as 'practice-theory-practice' (Browning 1996:9). Heyns and Pieterse (1990:7) describe practical theology as 'interpreting the interaction between the gospel and people'.

Ballard (1992) describes the work of practical theology in this way:

The special task of practical theology is to start with the concrete, historical, immediate reality, critically evaluating and enabling the practical life of the church in all its forms, drawing on the findings of fundamental, historical, and systematic theology. (p. 29)

I learned from these practical theologians, who never claimed to be postfoundationlist, that practical theology should start in a specific, concrete context. Practical theology must first reflect on the specific experiences of people.

Postfoundationalist approaches start by stating that there is no absolute truth. According to Shrag (1992):

From radical hermeneutics we learn that [for humans] there is no truth at the bottom of being, no final, no bedrock, correct interpretation [because of the limits of understanding and expression] that supplies the letztebegrundung. The search for such is misguided ... On the other hand, the hurried and facile claim of relativism that every interpretation is good as every other, is equally misguided. As no finite mind is privy to an absolute, strictly univocal, and limitless interpretive truth, so no finite mind can achieve a vision of all interpretations, which is required for judgment that all interpretative claims are relative. (p. 79)

Muller (2005:77) describes this way of thinking as 'always concrete, local and contextual, but at the same time $[i t]$ reaches beyond local contexts to transdisciplinary concerns' and 'it is a way of providing a responsible and workable interface between disciplines' (Muller 2011:3). Postfoundationalist practical theology can go beyond the specific local context to interdisciplinary territory. This approach is about having good communication between different disciplines.

Van Huyssteen (2006) writes as follows:

A postfoundationalist approach helps realize ... that we are not the intellectual prisoners of our own context or traditions, but that we are epistemically empowered to cross contextual, cultural, and disciplinary borders to explore critically the theories, meanings, and beliefs with which we and others construct our world. (p. 21)

Muller (2011:3) adds, 'the postfoundationalist approach forces us to firstly listen to the stories of people struggling in real life situations', to bring forth pastoral concerns to reflect on.

Muller (2005:73) argues that postfoundationalist practical theology happens whenever and wherever there is a reflection on practice, from the perspective of God's presence: 'it can be very spontaneous, informal, and local'. Postfoundationalist practical theology is always happening in that moment of practice. It is not imposed on the context but is born in the context as it gives the sources upon which to reflect.

\section{Postfoundationalist practical theology concerns in Nellmapius}

The postfoundationalist practical theology approach forces us to listen to the stories of people struggling in real life situations. The people of Nellmapius are struggling with poverty and community transformation. These are the pastoral concerns upon which our reflection must be based.

Postfoundationalist practical theology also believes in an interdisciplinary approach. Returning to the purpose of this article, practical theologians have not been trained in the issues of business and entrepreneurship. Therefore they must allow an interdisciplinary framework to apply to the pastoral concerns and challenges in Nellmapius, that is, poverty and community transformation They should invite economists, entrepreneurs, sociologists, psychologists, business operators and others to reflect with them on to these pastoral concerns. All of these disciplines will bring their perspectives to the reflection process. From those reflections, we (i.e. stakeholders from different disciplines and the community of Nellmapius) can take action to lead to a preferred, new reality for the Nellmapius community.

Muller (2011:3) spells out the foci of a holistic pastoral ministry in a context of poverty. I think this can also give theologians and pastoral ministers an authentic voice in the community empowerment process as they exemplify:

- real concern about real people. Concerns in this paradigm are never theoretical, but always local and embodied.

- a not-knowing approach, but rather one of active engagement

- an interdisciplinary approach, not on the basis of assimilation, but on the basis of transversal rationality

- a holistic perspective, in the sense of being fully committed to the real contextual story, and committed to exploring traditions of interpretation

- a social-constructionist approach, where a person is part of the development of a preferred reality that makes sense to him or her. Such an approach creates both the most profound and the most fragile moment: a moment of true pastoral concern.

Van Huyssteen (2006:148; see also Muller 2011) uses the term 'wide reflective equilibrium' to point to the optimal, but fragile, communal understanding we are capable of in any given moment. A postfoundationalist notion of reality enables us to communicate across boundaries and move transversally from context to context, from one tradition to another, from one discipline to another. He continues that in this wide reflective equilibrium, we find the safe but fragile public space we have been searching for, a space for shuttling back and forth between deep personal convictions and the principles that result from interpersonal judgements.

\section{Conclusion}

The poorest-of-the-poor community of Nellmapius needs social entrepreneurs who will work in the community and 
with them to develop models that can add value to their lives. These would be the kinds of people who would use their innovative thinking to be alert to the opportunities in the middle of the hopelessness found within this environment.

Dees (1998:4) celebrated the social entrepreneur as playing the role of a change agent in the social sector, by:

- adopting a mission to create and sustain social, not just private, value

- recognising and relentlessly pursuing new opportunities to serve that mission

- engaging in a process of continuous innovation, adaptation, and learning

- acting boldly without being limited by resources currently in hand

- exhibiting a heightened sense of accountability to the constituencies served and for the outcomes created.

In these ways, I see the social entrepreneur as acting as a steward of 'the works of His hands' and helping to co-create a better community.

\section{Acknowledgements Competing interests}

The author declares that he has no financial or personal relationships which may have inappropriately influenced him in writing this article.

\section{References}

Amra, R., Hlatshwayo, A. \& McMillan, L., 2013, 'SMME Employment in South Africa', paper presented at the biennial Conference of the Economic Society of South Africa, Bloemfontein, 25-27th September.

Austin, J., Stevenson, H. \& Wei-Skillern, J., 2006, 'Social and commercial entrepreneurship: Same, different or both?' Entrepreneurship Theory and Practice 30(1), 1-22. http://dx.doi.org/10.1111/j.1540-6520.2006.00107.x

Ballard, P., 1992, 'Can theology be practical?', in D. Willows \& J. Swinton (eds.), Spiritual dimension of pastoral care: Practical theology in a multidisciplinary context, pp. 27-35, Jessica Kingsley Publishers, Philadelphia, PA.

Browning, D.S., 1996, A foundational practical theology: Descriptive and strategic proposal, Fortress Press, Minneapolis, MN.

Bull, I. \& Willard, G.E., 1993, 'Towards a theory of entrepreneurship', Journal of Business Venturing 8(3), 183-195. http://dx.doi.org/10.1016/0883-9026(93)90026-2

Casson, M., 2010, Entrepreneurship: Theory, networks, history, Edward Elgar Publishing Limited, Cheltenham. http://dx.doi.org/10.4337/9781849805155

Chell, E., 2007, 'Social enterprise and entrepreneurship: Towards a convergent theory of the entrepreneur process', International Small Business Journal 25(1), 5-26. http://dx.doi.org/10.1177/0266242607071779

Cooper, A.C., 1985, 'The role of incubator organizations in the founding of growthoriented firms', Journal of Business Venturing 1(1), 75-86. http://dx.doi. org/10.1016/0883-9026(85)90008-4

Dees, J.G., 1998, 'The meaning of "social entrepreneurship"', draft report for the Kauffman Center for Entrepreneurial Leadership, Stanford University, Stanford, CA.

Drucker, P.F., 1964, Managing for results, Harper \& Row Publishers, New York, NY.
Fury, B., 2010, 'Social enterprise development in South Africa - Creating a virtuous Circle', in Tshikhululu Social Investments, viewed 24 June 2014, from http://www. tshikululu.org.za/uploads/files/TSI_research_social-enterprise_2010.pdf

Gissy, F., 1984, 'Incubator industrial buildings: A case study', Economic Development Review 2(2), 1-50.

Gree, A. \& Thurnik, C., 2003, 'Firm selection and industry evolution: Post country performance of new firm', Journal of Evolutionary Economics 4(4), 243-264.

Hamilton, T.T. \& Harper, D.A., 1994, 'The entrepreneur in theory and practice', Journal of Economic Studies 21(6), 3-18. http://dx.doi.org/10.1108/01443589410071391

Herrington, M. \& Turton, N., 2012, Global entrepreneurial monitor (GEM): South Africa viewed 25 August 2014, from http://www.gemconsortium.org/docs/download

Herrington, M., Kew, J. \& Kew, A., 2009, 'Tracking entrepreneurship in South Africa: A GEM perspective', Global entrepreneurship monitor South African Report, viewed 24 June 2014, from http://www.gemconsortium.org/docs/download/604.

Heyns, L.M. \& Pieterse, H.J.C., 1990, A primer in practical theology, Gnosis Books and Publishers, Pretoria.

Hornby, A.S., 2004, s.v. 'incubator', in Oxford Advanced Learner's Dictionary, 7th edn., n.p., Oxford University Press, Oxford, MS.

Mair, J. \& Marti, J., 2006, 'Social entrepreneur research: A source of explanation, prediction and delight', Journal of World Business 41(1), 36-44. http://dx.doi. org/10.1016/j.jwb.2005.09.002

Martin, R.L. \& Osberg, S., 2007, 'Social entrepreneurship: The case study for definition', Stanford Social Innovation Review, viewed 31 October 2013, from http://www. ssireview.org/articles/entry/social_entrepreneurship_the_case_for_definition

Mass, G. \& Herrington, M., 2006, Global entrepreneurship monitor (GEM): South African executive report, University of Cape Town Graduate School of Business, Cape Town.

McClelland, D.C., 1961, The achieving story, D. Van Nostrand, Princeton, NJ. http:// dx.doi.org/10.1037/14359-000

Muller, J.C., 2005, 'Postfoundationalist, HIV-positive practical theology', Practical Theology in South Africa 20(2), 72-88.

Muller, J.C., 2011, 'Postfoundational practical theology for a time of transition' HTS Teologies Studies/Theological Studies 67(1), Art. 837, 1-5. http://dx.doi. org/10.4102/hts.v67i1.837

Musara, M. \& Gwaindepi, C., 2014, 'Factors within the business regulatory environment affecting entrepreneurial activities in South Africa', Mediterranean Journal of Social Sciences 5(6), 109-116, viewed 02 September 2014, from http://dx.doi.10.5901/mjss.2014.v5n6p109

Olewale, F. \& Garwe, D., 2010, 'Obstacles to the growth of new SMEs in South Africa: Principal component analysis approach', African Journal of Business Management 4(5), 729-738.

Parker, S.C., 2004, Economics of self-employment and entrepreneurship, Cambridge University Press, Cambridge. http://dx.doi.org/10.1017/CBO9780511493430

Peredo, A.M. \& McLean, M., 2005, 'Social entrepreneurship: A critical review of the concept', Journal of World Business 41(1), 56-65. http://dx.doi.org/10.1016/j. jwb.2005.10.007

Schumpeter, J.A., 1934, Theory of economic development, 2nd edn., Harvard University Press, Cambridge.

Shrag, C.O., 1992, The resources of rationality: A response to the postmodern challenge, Indiana University Press, Bloomington, IN.

South Africa, Department of Trade and Industry, 1995, White paper on national strategy for the development and promotion of small business in South Africa, viewed 04 September 2014, from https://www.thedti.gov.za/sme_development/ docs/White_paper.pdf

South Africa, Department of Trade and Industry, 2008, Annual review of small business in South Africa: 2005-2007, viewed 04 September 2014, from http://www.dti.gov. za/sme_development/docs/smme_report.pdf

South Africa, National Planning Commission, 2011, National development plan 2030: Our future makes it work, viewed 20 June 2013, from http://www.npconline. co.za/MediaLib/Downloads/Downloads/Executive\%20Summary-NDP\%20 2030\%20-\%200ur\%20future\%20-\%20make\%20it\%20work.pdf.

Statistics South Africa, 2011, Census 2011, viewed 01 August 2014, from http://www. statssa.gov.za/publications/P03014/P030142011.pdf

Statistics South Africa, 2014, Quarterly Labour Force Survey (QLFS), 2nd Quarter, viewed 01 August 2014, from http://beta2.statssa.gov.za/?page id $=1854 \& P P N=P 0211 \& S C H=5875$

Van de Ven, A., 1993, 'The development of an infrastructure for entrepreneurship', Journal of Business Venturing 8(3), 211-230. http://dx.doi.org/10.1016/08839026(93)90028-4

Van Huyssteen, W., 2006, Alone in the world? Human uniqueness in science and theology, William B. Eerdmans Publishing Company, Grand Rapids, MI. 